\title{
KAJIAN PERMASALAHAN DAERAH ALIRAN SUNGAI JUWET KABUPATEN GUNUNGKIDUL DAN USULAN PENANGGULANGANYA
}

\author{
Ahmad Cahyadi \\ Program BEASISWA UNGGULAN BPKLN KEMDIKBUD RI pada Magister Perencanaan Pengelolaan \\ Pesisir dan Daerah Aliran Sungai Fakultas Geografi Universitas Gadjah Mada Yogyakarta \\ Email: ahya.edelweiss@gmail.com
}

\section{INTISARI}

Makalah ini bertujuan untuk menginventarisasi permasalahan yang terjadi di DAS Juwet dan memberikan usulan penanggulangannya. Permasalahan di DAS Juwet terdiri dari erosi, longsor, sumberdaya air dan airtanah, unsur hara dalam tanah yang rendah, dan tekanan penduduk terhadap lahan yang tinggi. Penyelesaian masing-masing masalah dilakukan dengan prinsip pengelolaan DAS terpadu. Pengelolaan DAS harus dimulai dengan menginventarisasi permasalahan DAS kemudian menyusun prioritas penyelesaian dan merencanakan penyelesaian masalah DAS secara terpadu melibatkan semua elemen yang berkepentingan, sehingga penerapan rencana pengelolaan DAS akan lebih mudah dan efektif.

Kata Kunci: Pengelolaan DAS Terpadu, Permasalahan DAS

\section{PENDAHULUAN}

DAS adalah daerah yang dibatasi oleh punggung-punggung gunung atau pegunungan, di mana air hujan yang jatuh di daerah tersebut akan mengalir menuju sungai utama pada suatu titik atau stasiun yang ditinjau (Triatmodjo, 2009). Seyhan (1990) menyatakan bahwa DAS adalah lahan total dan permukaan air yang dibatasi oleh suatu batas air berupa topografi dan memberikan sumbangan terhadap debit sungai pada suatu irisan melintang tertentu. Penentuan bats-batas DAS menurut Triatmodjo (2009) dapat ditentukan berdasarkan bentuk kontur pada peta topografi. Batas DAS akan menghubungkan titik-titik tertinggi yang mengelilingi DAS.

Asdak (2007) mengatakan bahwa daerah aliran sungai adalah satu kesatuan ekosistem yang terdiri dari subsistem hulu, tengah dan hilir. Selain itu, Asdak (2007) menyatakan bahwa dengan memandang DAS sebagai suatu ekosistem, maka setiap masukan ke dalam DAS dapat dievaluasi proses yang telah terjadi dan dan proses yang sdang terjadi dengan cara melihat keluaran dari DAS dari outletnya. Input di daerah aliran sungai adalah air hujan, sedangkan outputnya berupa aliran air, muatan sedimen dan unsur hara. DAS sebagai suatu ekosistem memiliki beberapa komponen, yaitu manusia dengan segala aktivitas dan ilmu serta teknologinya, vegetasi, tanah dan sistem sungai. Hujan yang jatuh ke dalam DAS akan mengalami interaksi dengan komponen-komponen ekosistem DAS tersebut dan akan menghasilkan keluaran berupa debit, muatan sedimen dan material lainnya yang terbawa oleh aliran sungai.

"Pengelolaan DAS Secara Terpadu atau Integrated River Basin Management (IRBM) adalah sebuah falsafah, proses dan sekaligus sebuah strategi pelaksanaan untuk mencapai keseimbangan yang lestasi antara penggunaan dan perlindungan semua sumberdaya lingkungan di suatu daerah tangkapan air, dan untuk mengembangkan suatu masyarakat yang lestari melalui hubungan kemitraan antara para stakeholder, masyarakat dan pemerintah dalam suatu proses pengelolaan."

(Pollard, 2002 dalam Both ENDS dan Gomukh, 2005).

Pendekatan pengelolaan DAS secara terpadu muncul pada konferensi internasional di Mar del Plata tahun 1977. Secara ekologi, pendekatan ini bertujuan untuk menggabungkan semua subekosistem di dalam DAS dalam satu pengelolaan. Sedangkan secara kelembagaan, pendekatan ini bertujuan untuk memudahkan proses administrasi, koordinasi, serta yang paling penting adalah pembagian tugas yang sesuai dengan bidang masing-masing institusi atau badan di mana perencanaan dan pengembangan semua sektor dikoordinasikan melalui diskusi dan pembuatan keputusan antar departemen dengan mempertimbangkan hasil penelitian atau masukan dari para ilmuan.

Anjuran pemakaian pendekatan terpadu dalam pengelolaan sumberdaya air muncul setelah Konferensi PBB mengenai lingkungan dan pembangunan (UNCED) tahun 1992 di Rio de Janeiro, Brazil yang menghasilkan sebuah program tindakan bertajuk "Agenda 21" (Murdiyarso, 2003). Pengelolaan DAS dalam agenda 21 masuk dalam dokumen prinsip-prinsip kehutanan yang 
menyatakan pentingnya hutan, penyerapan karbon atmosfer, perlindungan keanekaragaman hayati dan pengelolaan DAS. Selain itu, agenda 21 ini juga mengharuskan perubahan administratif dalam pengelolaan sumberdaya air, menciptakan ruang dialog antara stakeholder, pemerintah dan masyarakat, pelibatan organisasi masyarakat, melibatkan masyarakat lokal dalam pengambilan keputusan untuk menyelesaikan konflik dan harus menanggapi semua keluhan yang muncul akibat pengelolaan sumberdaya air. (Both ENDS dan Gomukh, 2005.)

Pengelolaan DAS dapat dirancang dengan terlebih dahulu nmenginventarisasi permasalahanpermasalah yang ada di dalam DAS. Hal ini karena permasalahan antara satu DAS dengan DAS yang lain seringkali berbeda bahkan sangat berbeda. Maka, pengelolaan DAS harus dimulai dengan menginventarisasi permasalahan DAS kemudian menyusun prioritas penyelesaian dan merencanakan penyelesaian masalah DAS secara terpadu melibatkan semua elemen yang berkepentingan, sehingga penerapan rencana pengelolaan DAS akan lebih mudah dan efektif.

\section{LOKASI KAJIAN}

Wilayah penelitian yang digunakan adalah Daerah Aliran Sungai (DAS) Juwet yang secara administratif masuk ke dalam wilayah Kabupaten Gunungkidul, Propinsi Daerah Istimewa Yogyakarta. Berdasarkan peta rupa bumi Indonesia (RBI) skala 1: 25.000 Tahun 1999 lembar 1408-311 (Wonosari), lembar 1408-313 (Jabung), dan lembar 1408-314 (Cawas), wilayah DAS Juwet meliputi tiga kecamatan, yaitu Kecamatan Gedangsari, Kecamatan Patuk, dan Kecamatan Nglipar. Wilayah DAS Juwet di Kecamatan Gedangsari meliputi tiga desa yaitu Desa Hargomulyo, Desa Mertelu dan Desa Ngalang. Wilayah DAS Juwet di Kecamatan Nglipar mencakup tiga desa yaitu Desa Kedungpoh, Desa Pengkol dan Desa Pilangrejo, sedangkan wilayah DAS Juwet di Kecamatan Patuk hanya mencakup sebagian dari Desa Nglegi.

Tabel 1. Daerah administratif desa di DAS Juwet

\begin{tabular}{|l|l|r|r|}
\hline \multicolumn{1}{|c|}{ Desa } & Kecamatan & Luas Wilayah Dalam DAS (ha) & \% Luas \\
& & $1.160,7$ & 35,57 \\
\hline Hargomulyo & Gedangsari & 622,4 & 19,07 \\
\hline Mertelu & Gedangsari & $1.082,6$ & 33,18 \\
\hline Ngalang & Gedangsari & 7,0 & 0,21 \\
\hline Kedungpoh & Nglipar & 237,4 & 7,28 \\
\hline Pengkol & Nglipar & 20,5 & 0,63 \\
\hline Pilangrejo & Nglipar & 132,5 & 4,06 \\
\hline Nglegi & Patuk & $\mathbf{3 . 2 6 3 , 1}$ & $\mathbf{1 0 0 , 0 0}$ \\
\hline
\end{tabular}

Sumber: Analisis sistem informasi geografis

Berdasarkan hasil analisis dengan menggunakan sistem informasi geografis (SIG), diketahui bahwa luas DAS Juwet adalah 3.263,1 hektar (ha). Secara astronomis DAS Juwet terletak pada koordinat 7049'49" LS - 7052'16" dan pada koordinat 110 $34^{\prime} 13^{\prime \prime}$ BT - 110 $35^{\prime} 3^{\prime \prime}$ BT, atau pada sistem proyeksi Universal Transverse Mercator (UTM) terletak pada $451.242 \mathrm{mT}$ - $459.687 \mathrm{mT}$ dan pada 9.127.451 $\mathrm{mU}-9.135 .470 \mathrm{mU}$.

Batas wilayah DAS Juwet adalah sebagai berikut:
a. Batas sebelah Timur : DAS Dondong
b. Batas sebelah Selatan : Sungai Oyo
c. Batas sebelah Barat : DAS Widoro
d. Batas sebelah Utara : DAS Dengkeng 


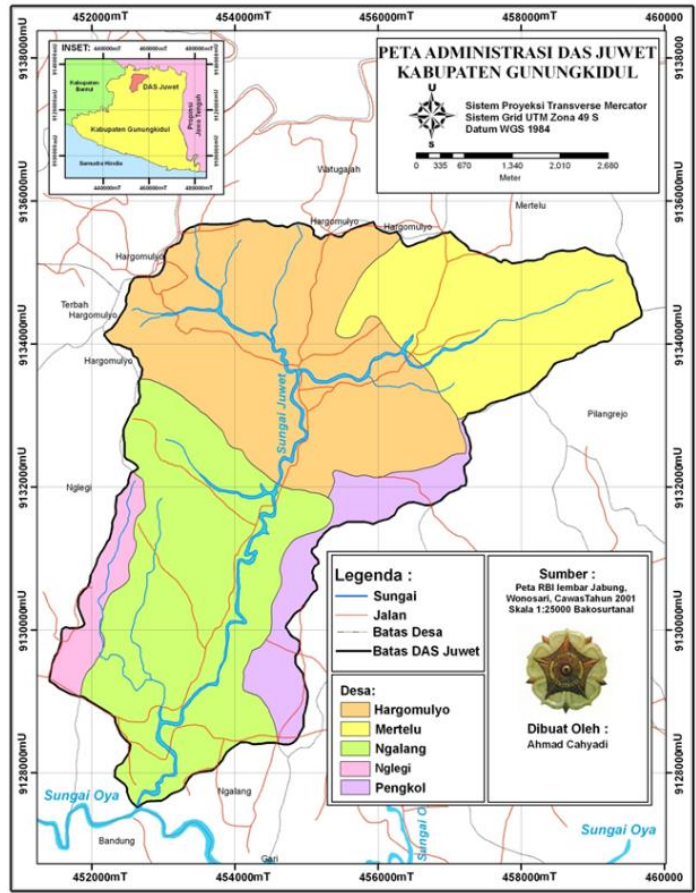

Gambar 1. Peta administrasi DAS Juwet

\section{PERMASALAHAN DAS JUWET}

\section{A. Erosi}

Erosi diartikan sebagai peristiwa pindahnya atau terangkutnya tanah atau bagian-bagian tanah dari suatu tempat ke tempat yang lain oleh media alami (Arsyad, 1989). Hal yang serupa diungkapkan oleh Rahim (2006) yang menyatakan bahwa erosi adalah suatu peristiwa hilang atau terkikisnya tanah atau bagian tanah dari suatu tempat ke tempat yang lain, baik yang disebabkan oleh pergerakan air, angin, dan atau es. Definisi lain tentang erosi dikemukakan oleh Utomo (1994) yang mengemukakan bahwa erosi adalah proses perataan kulit bumi yang terjadi dengan penghancuran, pengangkutan, dan pengendapan.

Proses erosi oleh air paling tidak terdiri dari satu tahap, yaitu dispersi tanah oleh butitr hujan dan atau oleh limpasan (Rahim, 2006). Lebih lanjut Rahim (2006) menjelaskan bahwa terdapat beberapa tahapan dalam erosi, yaitu; (i) benturan butir-butir hujan dengan tanah, (ii) percikan tanah oleh butir hujan ke semua arah, (iii) penghancuran bongkah tanah oleh butiran hujan, (iv) pemadatan tanah, (v) penggenangan air di permukaan, (vi) pelimpasan air karena adanya penggenangan dan kemiringan lahan, (vii) pengangkutan partikel terpercik dan atau massa tanah yang terdispersi oleh limpasan. Utomo (1994) menyatakan bahwa penghancuran agregat tanah tidak hanya dapat terjadi oleh adanya pukulan dari jatuhnya air hujan, tetapi dapat pula oleh air limpasan serta gerusan yang terjadi oleh material yang terangkut limpasan terhadap permukaan tanah yang dilewatinya.

Menurut bentukknya, erosi dibedakan menjadi erosi lembar, erosi alur, erosi parit, erosi tebing sungai, erosi longsor, dan erosi internal (Arsyad, 1989). Hal yang berbeda dikemukakan oleh Rahim (2006) di mana erosi menurut bentuknya dibagi menjadi erosi percikan, erosi lembar, erosi alur, erosi selokan (parit), erosi longsor dan erosi pinggir sungai. Rahim (2006) berpendapat bahwa erosi internal bukan merupakan jenis erosi karena perpindahan material terjadi secara vertikal (butiran halus di bagian atas mengisi rongga antar butir di bagian bawahnya).

Erosi percik adalah erosi yang terjadi oleh akibat benturan air hujan yang jatuh dengan permukaan tanah. Erosi ini akan meningkat seiring dengan semakin besarnya butir hujan dan menurun dengan semakin besarnya tebal genangan aliran permukaan (Utomo, 1994). Rahim (2006) menambahkan bahwa erosi percik tidak akan terjadi apabila tebal genangan telah mencapai tiga kali dari besar butir hujan yang jatuh.

Erosi lembar adalah pengangkutan lapisan tanah yang merata tebalnya dari suatu permukaan bidang tanah (Arsyad, 1989).Erosi ini disebut juga sebagai erosi limpasan permukaan. Agresivitas aliran permukaan dipengaruhi oleh gaya gravitasi, tebal aliran, viskositas aliran dan kecepatan aliran 
(Utomo, 1994). Erosi permukaan tidak hanya disebabkan oleh gesekan oleh aliran permukaan, namun juga disebabkan oleh gesekan material yang ikut terangkut oleh aliran permukaan.

Erosi alur adalah erosi yang terjadi karena air terkonsentrasi dan mengalir pada tempat-tempat tertentu di permukaan tanah sehingga memindahkan tanah lebih banyak dibandingkan dengan daerah sekitarnya, sedangkan erosi parit adalah erosi yang proses terjadinya dengan erosi alur, hanya saja parit yang terbentuk tidak dapat dikembalikan dengan pengolahan biasa. Ukuran saluran disebut parit apabila ukuran lebarnya minimal $40 \mathrm{~cm}$ dan memiliki kedalaman minimal $25 \mathrm{~cm}$ (Arsyad, 1989). Parit yang besar akan membentuk aliran sungai, di mana pada tempat ini akan terjadi erosi tebing sungai. Erosi tebing sungai dapat terjadi akibat aliran sungai mengikis bagian pinggir sungai dan biasanya banyak terjadi pada suatu kelokkan sungai.

Besarya erosi di DAS Juwet adalah sebesar 370.456,3 ton/tahun (Aziz, 2008). Besarnya erosi tersebut didapatkan dari penelitian sebelumnya yang menghitung erosi di DAS Juwet dengan menggunakan metode USLE. Penggunaan lahan yang paling banyak menyumbang erosi adalah penggunaan lahan tegalan atau ladang. Hal ini nampak dari penelitian sebelumnya yang dilakukan oleh Azis (2008) yang ditampilkan pada Tabel 3. Kondisi ini terjadi karena penggunaan lahan tegalan memiliki luas yang paling besar $(72,7 \%)$, memiliki luas lahan kritis yang paling besar yakni sebesar $47,64 \%$ dari luas DAS Juwet (Azis, 2008), penggunaan lahan tegalan yang menempati lokasi dengan kemampuan lahan yang tidak sesuai (miss use) yakni seluas $2.228,7$ hektar atau $68,30 \%$ dari luas DAS Juwet ( Azis, 2008) serta didominasi dengan pengolahan lahan yang minimum (Puspasari, 2010).

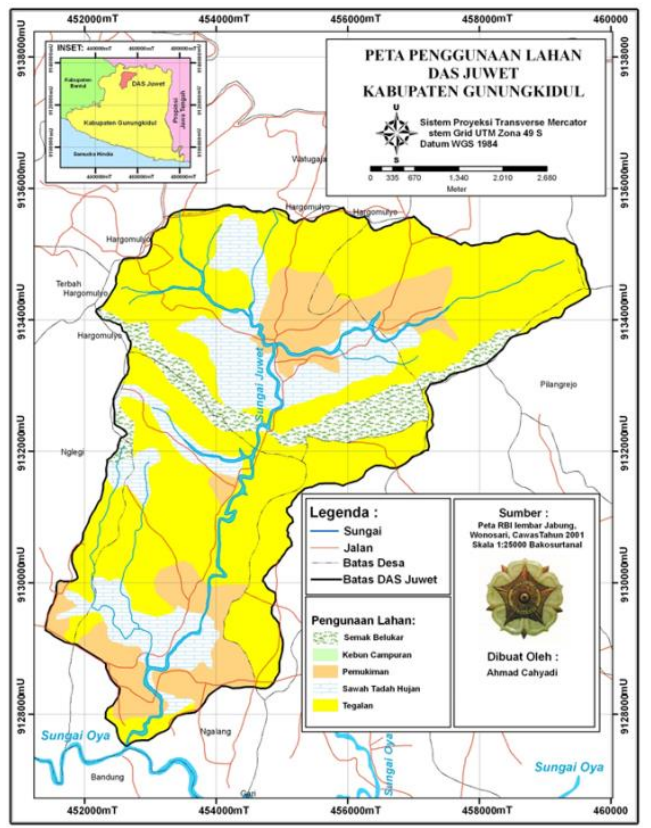

Gambar 2. Peta penggunaan lahan DAS Juwet

Tabel 2. Penggunaan lahan di DAS Juwet

\begin{tabular}{|l|r|r|}
\hline \multicolumn{1}{|c|}{ Penggunaan lahan } & \multicolumn{1}{c|}{ Luas (ha) } & \% Luas \\
\hline Semak Belukar & 186 & 5,7 \\
\hline Kebun Campuran & 32,1 & 1,0 \\
\hline Tegalan & 2372,6 & 72,7 \\
\hline Sawah Tadah Hujan & 405,4 & 12,4 \\
\hline Permukiman & 267 & 8,2 \\
\hline Jumlah & $\mathbf{3 2 6 3 , 1}$ & $\mathbf{1 0 0 , 0}$ \\
\hline
\end{tabular}

Sumber: Anaslis sistem informasi geografis 
Tabel 3. Laju erosi pada masing-masing penggunaan lahan di DAS Juwet

\begin{tabular}{|c|l|r|}
\hline No. & Jenis Penggunaan Lahan & \multicolumn{1}{|c|}{ Laju Erosi (ton/tahun) } \\
\hline 1 & Semak Belukar & $18.440,6$ \\
\hline 2 & Kebun Campuran & $5.343,3$ \\
\hline 3 & Tegalan & $250.263,5$ \\
\hline 4 & Sawah Tadah Hujan & $4.829,3$ \\
\hline 5 & Permukiman & $91.579,6$ \\
\hline \multicolumn{2}{|c|}{ Jumlah } & $370.456,3$ \\
\hline
\end{tabular}

Sumber: Azis (2008)

\section{B. Longsor}

Kajian mengenai longsor di DAS Juwet telah dilakukan oleh Harlan (2010). Harlan menyatakan bahwa tingkat kerentanan longsor di DAS Juwet dapat dibagi menjadi tiga, yaitu tingkat kerentanan rendah, sedang dan tinggi. Kerentanan longsor rendah seluas $270,20 \mathrm{Ha}$ atau $8,2 \%$ dari total wilayah DAS Juwet. Tingkat kerentanan ini terletak di bagian hilir Das Juwet. Kerentanan longsor sedang terletak di bagian tengah DAS dengan luas 2.225,8 Ha atau 69,1\%, sedangkan kerentanan longsor tinggi terdapat di bagian hulu yang merupakan bagian dari Perbukitan baturagung (terletak tepat di atas escarpment) dengan luas $736,9 \mathrm{Ha}$ atau 22,5\%. Kerentanan longsor yang tinggi selain disebabkan oleh batuan yang mengalami lapuk yang lanjut dan batuan dasar yang kedap air, juga disebabkan karena kemiringan lereng yang tinggi dan pemanfaatan lahan yang tidak sesuai dengan kemampuan lahannya serta adanya faktor pemicu berupa curah hujan yang cukup tinggi dan terdapat pada wilayah dekat sesar aktif yang sering terjadi gempa.

\section{Terbatasnya sumberdaya Air Permukaan dan airtanah}

Hasil perhitungan hujan wilayah DAS Juwet menunjukkan bahwa hujan maksimun terjadi pada setengah bulan kedua dari Bulan Januari yakni $210 \mathrm{~mm}$, sedangkan hujan paling rendah terjadi pada Bulan Agustus sampai setengah bulan pertama Bulan September yakni tidak ada kejadian hujan. Analisis terhadap hujan dan evapotranspirasi aktual yang ditunjukkan pada Gambar 3. Gambar tersebut menunjukkan bahwa defisit air secara meteorologis di DAS Juwet terjadi pada setengah bulan kedua Bulan Mei, setengah bulan pertama Bulan Juni, dan setengah bulan kedua Bulan Juli sampai dengan setengah pertama Bulan Oktober. Kondisi ini dapat dicirikan dengan nilai curah hujan yang lebih kecil dibandingkan dengan besarnya evapotranspirasi aktual pada waktu yang sama.

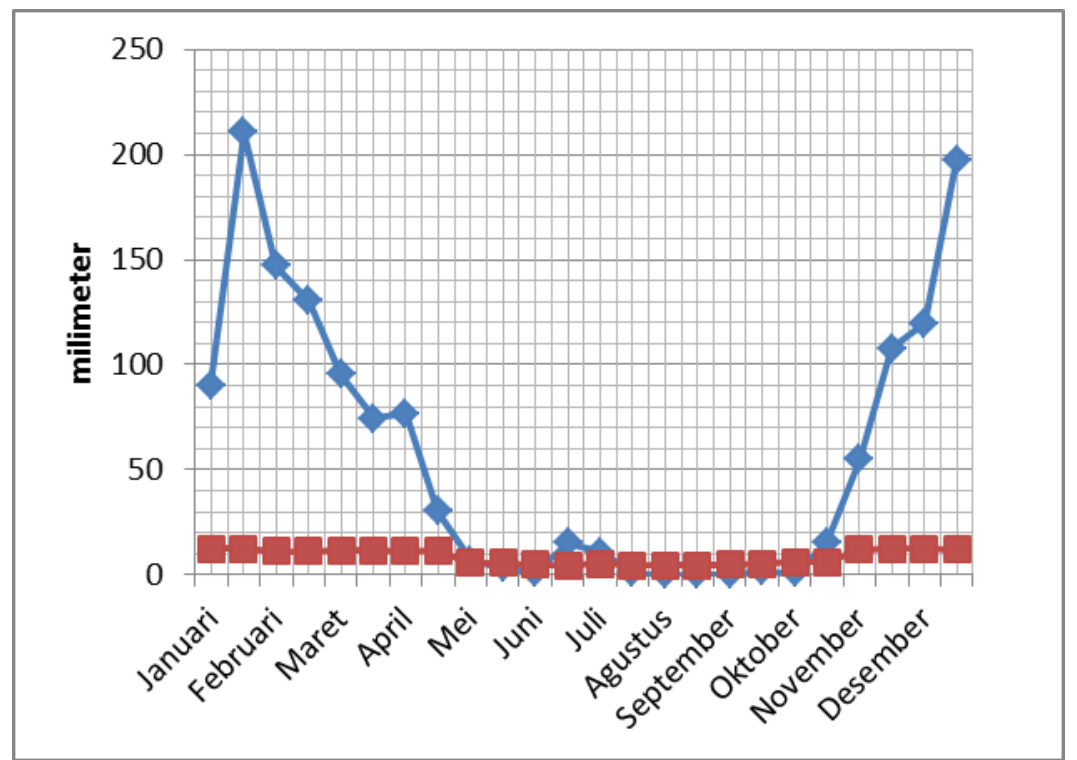

Gambar 3. Grafik hujan dan evapotranspirasi aktual di DAS Juwet (Cahyadi dkk, 2011)

Hasil pemodelan debit aliran dengan menggunakan Model Mock menghasilkan variasi debit rata-rata setengah bulanan $(Q)$ yang kecil, yakni dengan debit minimum $12,57 \mathrm{~m}^{3} / \mathrm{s}$ dan maksimum $17,55 \mathrm{~m}^{3} / \mathrm{s}$. Debit yang dihasilkan adalah debit rata-rata setengah bulanan yang dihasilkan oleh debit- 
debit yang lebih besar dan debit-debit yang lebih kecil yang terjadi selama setengah bulan. Nilai ini pada kenyataannya terlalu besar khususnya untuk debit pada musim kemarau. Hal ini karena menurut masyarakat sekitar, debit aliran Sungai Juwet pada musim kemarau biasanya nol atau sungai pada kondisi kering. Sehingga seharusnya nilai debit aliran pada musim kemarau (Mei sampai Oktober) adalah nol.

\section{Unsur Hara yang Rendah di Dalam Tanah}

Kandungan karbon organik tanah di DAS Juwet berdasarkan klasifikasi kandungan karbon organik tanah dari Balai Penelitian Tanah, Balai Besar Litbang Sumber Daya Lahan Pertanian, Badan Penelitian dan Pengembangan Pertanian, Departemen Pertanian Republik Indonesia (2009) yang terdapat pada Tabel 4 termasuk dalam klasifikasi sangat rendah sampai dengan sedang. Hal ini didasarkan pada penelitian Worosuprojo, Nurjani dan Ashari (2010) yang menunjukkan bahwa ratarata kandungan karbon organik tanah di DAS Juwet adalah 0,74\%. Hal tersebut berarti bahwa ratarata kandungan karbon organik tanah di DAS Juwet masuk dalam klasifikasi sangat rendah. Kondisi demikian sangat terkait dengan kondisi DAS Juwet yang didominasi oleh lahan kritis sangat berat seperti yang tampak pada Tabel 5 .

Tabel 4. Klasifikasi kandungan karbon organik tanah

\begin{tabular}{|c|c|c|}
\hline Nilai Bahan Organik & Nilai Karbon Organik & Harkat/Klasifikasi \\
\hline$<2 \%$ & $<1,16 \%$ & Sangat Rendah \\
\hline $2 \%-3,5 \%$ & $1,16 \%-2,03 \%$ & Rendah \\
\hline $3,5 \%-5 \%$ & $2,03 \%-2,9 \%$ & Sedang \\
\hline $5 \%-8,5 \%$ & $2,9 \%-4,93 \%$ & Tinggi \\
\hline$>8,5 \%$ & $>4,93 \%$ & Sangat Tinggi \\
\hline
\end{tabular}

Sumber: Balai Penelitian Tanah, Balai Besar Litbang Sumber Daya Lahan Pertanian, Badan Penelitian dan Pengembangan Pertanian, Departemen Pertanian Republik Indonesia (2009)

Tabel 5. kondisi kekritisan lahan di DAS Juwet

\begin{tabular}{|c|c|c|}
\hline Kondisi Lahan & Luas (Ha) & \% Luas \\
\hline Tidak Kritis & 512,9 & 15,72 \\
\hline Potensial Kritis & 48,4 & 1,48 \\
\hline Kritis Berat & 90,1 & 2,78 \\
\hline Kritis Sangat Berat & $2.594,9$ & $\mathbf{7 9 , 5 2}$ \\
\hline Jumlah & $\mathbf{3 2 6 3 . 1}$ & $\mathbf{1 0 0}$ \\
\hline
\end{tabular}

Sumber: Azis (2008)

Hasil perhitungan menunjukkan bahwa kehilangan karbon organik tanah dalam bentuk suspensi di DAS Juwet adalah sebesar 253,45 ton/tahun. Jumlah ini sangat sedikit jika dibandingkan dengan jumlah sedimen suspensi yang keluar dari DAS Juwet, yakni sebesar 102.079,5 ton/tahun atau $0,24 \%$. Jumlah tersebut lebih sedikit dibandingkan dengan rata-rata kandungan karbon organik dalam tanah di DAS Juwet yakni $0,74 \%$. Hal ini berarti sebagian dari karbon organik tanah yang tererosi mengalami pengendapan di dalam DAS atau keluar dari dalam DAS dalam bentuk sedimen dasar.

Besarnya nilai pengendapan hasil erosi dapat diperkirakan dengan menghitung sediment delivery ratio (SDR) dari suatu DAS. SDR diperoleh dengan membandingkan total erosi yang terjadi di dalam DAS dengan jumlah sedimen total yang keluar dari dalam DAS. Karena data sedimen total tidak tersedia, maka digunakan asumsi bahwa jumlah sedimen suspensi adalah $80 \%-90 \%$ dari total sedimen (Mahendra 2009). Berdasarkan hal tersebut, maka jumlah sedimen total yang keluar dari DAS Juwet selama satu tahun adalah $113.421,7$ ton/tahun sampai dengan 127.599,4 ton/tahun (Cahyadi, 2011).

Besarnya erosi di DAS Juwet diperkirakan dengan menggunakan metode USLE. Besarya erosi di DAS Juwet adalah sebesar 370.456,3 ton/tahun Maka nilai SDR DAS Juwet adalah sebersar $30,62 \%-34,44 \%$. Hal ini berarti bahwa hanya 30,62\% - 34,44\% dari jumlah tanah tererosi yang keluar dari DAS Juwet, sedangkan $65.56 \%$ - 69,38\% dari tanah tererosi akan mengendap di dalam DAS. 
Tabel 1. Perhitungan Kehilangan Karbon Organik Tanah di DAS Juwet

\begin{tabular}{|c|c|r|r|r|r|}
\hline \multirow{2}{*}{ Bulan } & $\begin{array}{c}\text { Tengah } \\
\text { Bulan }\end{array}$ & $\begin{array}{c}\text { Kehilangan Karbon } \\
\text { Organik Tanah (ton) }\end{array}$ & Bulan & $\begin{array}{c}\text { Kehilangan } \\
\text { Karbon Organik } \\
\text { Tanah (ton) }\end{array}$ \\
\hline \multirow{2}{*}{ Januari } & I & 11,19 & Juli & I & 9,24 \\
\cline { 2 - 6 } & II & 15,38 & & II & 9,11 \\
\hline \multirow{2}{*}{ Februari } & I & 13,04 & Agustus & I & 9,11 \\
\cline { 2 - 6 } & II & 12,48 & & II & 9,11 \\
\hline \multirow{2}{*}{ Maret } & I & 11,37 & September & I & 9,11 \\
\cline { 2 - 6 } & II & 10,75 & & II & 9,11 \\
\hline \multirow{2}{*}{ April } & II & 10,83 & Oktober & I & 9,11 \\
\hline \multirow{2}{*}{ Mei } & I & 9,57 & & II & 1 \\
\cline { 2 - 6 } & II & 9,13 & November & I & 10,20 \\
\hline \multirow{2}{*}{ Juni } & I & 9,11 & & II & 11,71 \\
\cline { 2 - 6 } & II & 9,11 & Desember & I & 12,10 \\
\hline
\end{tabular}

Sumber: Cahyadi, dkk (2011)

\section{E. Tekanan Penduduk yang Tinggi}

Kependudukan merupakan aspek sangat sangat penting dalam pengelolaan lingkungan suatu DAS.Hal ini karena faktor kependudukan akan berpengaruh terhadap beberapa aspek yang lain yang akan mempengaruhi kondisi suatu DAS. Manusia akan mempengaruhi penggunaan lahan, pemanfaatan sumberdaya dan kegiatan konservasi ataupun perlindungan terhadap sumberdaya di suatu DAS. Penentuan jumlah penduduk di suatu DAS mememiliki beberapa kendala, diantaranya adalah karena data kependudukan memiliki unit wilayah administrasi, sementara batas DAS adalah batas alam yang sering tidak sama dengan batas administrasi. Oleh karena itu, maka untuk menentukan jumlah penduduk DAS Juwet dilakukan dengan menggunakan rumus rerata timbang.Rumus ini berasumsi bahwa jumlah penduduk dalam suatu DAS berbanding lurus dengan luas wilayah administrasi yang masuk dalam wilayah DAS.

Tabel 3.10. Jumlah pendudukberdasarkan administratif di DAS Juwet

\begin{tabular}{|c|c|c|c|c|c|c|c|c|}
\hline \multirow[t]{2}{*}{ Desa } & \multirow[t]{2}{*}{$\begin{array}{l}\text { Luas Wilayah } \\
\text { Administratif } \\
(\mathrm{Ha})\end{array}$} & \multirow{2}{*}{$\begin{array}{l}\text { Luas } \\
\text { Wilayah } \\
\text { Dalam } \\
\text { DAS } \\
(\mathrm{Ha})\end{array}$} & \multicolumn{3}{|c|}{$\begin{array}{c}\text { Jumlah Penduduk } \\
\text { Dalam Wilayah } \\
\text { Administrasi }\end{array}$} & \multicolumn{3}{|c|}{$\begin{array}{c}\text { Jumlah Penduduk dalam } \\
\text { DAS Juwet }\end{array}$} \\
\hline & & & 2007 & 2008 & 2009 & 2007 & 2008 & 2009 \\
\hline Hargomulyo & 1160.7 & 1160.7 & 7959 & 7676 & 7199 & 7959 & 7676 & 7199 \\
\hline Mertelu & 973.8 & 622.4 & 4386 & 4278 & 3836 & 2803 & 2734 & 2452 \\
\hline Ngalang & 1481.7 & 1082.6 & 7011 & 8874 & 8172 & 5123 & 6484 & 5971 \\
\hline Kedungpoh & 1080 & 7.0 & 5644 & 5673 & 5400 & 37 & 37 & 35 \\
\hline Pengkol & 884 & 237.4 & 5376 & 5653 & 5670 & 1444 & 1518 & 1523 \\
\hline Pilangrejo & 876 & 20.5 & 3548 & 3552 & 3563 & 83 & 83 & 83 \\
\hline Nglegi & 930.8 & 132.5 & 3204 & 3210 & 3193 & 456 & 457 & 455 \\
\hline Jumlah & 7387 & 3263.1 & 39135 & 40924 & 39042 & 19911 & 20997 & 19726 \\
\hline
\end{tabular}

Sumber: Analisis sistem informasi geografis dan Gunungkidul Dalam Angka Tahun 2007, 2008, dan 2009 

berikut:

Rumus yang digunakan untuk menghitung jumlah penduduk di dalam DAS adalah sebagai

$$
\text { JPD = (LAD/LD) } \times \text { PA }
$$

Keterangan:

JPD : Jumlah penduduk di dalam DAS

LAD : : Luas wilayah administrasi yang berada di dalam DAS

LD : Luas DAS

PA : Jumlah penduduk dalam wilayah administratif

Tabel 3.11. Tekanan penduduk di DAS Juwet

\begin{tabular}{|l|l|l|}
\hline Desa & Tekanan Penduduk & Keterangan \\
\hline Hargomulyo & 2,28 & Tinggi \\
\hline Mertelu & 1,47 & Sedang \\
\hline Ngalang & 1,51 & Sedang \\
\hline Kedungpoh & 2,87 & Tinggi \\
\hline Pengkol & 2,59 & Tinggi \\
\hline Pilangrejo & 2,01 & Tinggi \\
\hline Nglegi & 1,17 & Sedang \\
\hline \multicolumn{2}{|l|}{ Sumber: Azis (2008) }
\end{tabular}

Faktor penduduk sangat mempengaruhi kondisi DAS, terutama terkait dengan penggunaan lahan. Salah satu indeks yang digunakan untuk menggambarkan pengaruh penduduk yang berprofesi sebagai petani terhadap lahan adalah indeks tekanan penduduk. Perhitungan indeks ini ditujukan untuk menentukan tingkat tekanan potensial petani terhadap perubahan penggunaan lahan untuk aktifitas pertanian. Tabel 3.11. menunjukkan bahwa nilai tekanan penduduk di Das Juwet (menggunakan unit analisis desa) adalah lebih dari 1. Artinya bahwa tekanan penduduk terhadap lahan di DAS Juwet tinggi dan berpotensi untuk menjadikan luas lahan pertanian di DAS Juwet akan semakin luas. Hal ini juga sesuai dengan kondisi DAS Juwet sekarang dengan luas tegalan sebesar $72,7 \%$ dan luas sawah tadah hujan sebesar $12,4 \%$, atau berarti bahwa penggunaan lahan untuk pertanian di DAS Juwet adalah sebesar $85,1 \%$ dari luas wilayah DAS Juwet.

\section{USULAN PENYELESAIAN MASALAH DAS JUWET}

\section{A. Penyelesaian Masalah Erosi}

Penyelesaian masalah erosi dapat dilakukan dengan:

1. Metode vegetatif, metode ini dilakukan dengan menggunakan tanaman dan sisasisanya untuk mengurangi daya rusak hujan dan daya rusak aliran.

Termasuk dalam metode vegetatif adalah; (a) penanaman tanaman yang menutupi lahan terus-menerus, (b) penenanaman dalam strip, (c) pergiliran tanaman dengan tanaman pupuk hijau atau tanaman penutup tanah, (d) sistem pertanian hutan, (e) pemanfaatan sisa tanaman sebagai mulsa, dan (f) menanami saluran pembuangan dari lahan dengan rumput.

2. Metode Mekanik

Pengolahan tanah secara mekanik adalah semua perlakuan fisik mekanis yang diberikan terhadap tanah dan pembuatan bangunan untuk mengurangi dampak dari aliran permukaan serta peningkatan kemampuan penggunaan tanah. Termasuk dalam metode ini adalah; (a) pengolahan tanah, (b) pengolahan tanah menurut kontur, (c) pembuatan guludan, (d) pembuatan teras, (e) pembuatan dam penghambat, waduk, roral atau tanggul, dan (6) perbaikan drainase dan irigasi. 


\section{B. Penyelesaian Masalah Longsor}

Masalah bencana tanah longsor dapat dilakukan dengan:

1. Penyampaian dan penyebaran informasi kepada masyarakat tenatang prosesproses longsor, faktor penyebab, tanda-tanda kejadian longsor,serta lokasi-lokasi dengan kerentanan longsor yang tinggi. Hal ini akan meningkatkan kesiapsiagaan masyarakat dalam menghadapi longsor.

2. Mengatur pemanfaatan lahan yang sesuai dengan kemampuannya sehingga pada lahan yang memiliki kerentanan longsor yang tinggi tidak digunakan sebagai permukiman.

3. Melakukan relokasi pada beberapa rumah yang terdapat pada lokasi dengan kerentanan longsor yang tinggi.

\section{Penyelesaian Masalah Kandungan Unsur Hara yang Rendah}

Masalah rendahnya kandungan unsur hara yang rendah dapat diselesaikan dengan:

1. Pencegahan erosi, hal ini akan menyebabkan unsur hara yang terbentuk secara alami ataupun penambahan oleh manusia tidak segera hilang.

2. Pembuatan pupuk dari bahan lokal misalnya pupuk kompos dari sisa tanaman dan pupuk kandang.

3. Pemupukan dengan pupuk buatan dengan kadar yang ditentukan berdasarkan penelitian atau kajian.

4. Melakukan rotasi tanaman sehingga dalam satu tahun tidak hanya terdapat satu tanaman saja.

\section{Penyelesaian Masalah Sumberdaya Air}

Permasalahan sumberdaya air dapat diselesaikan dengan:

1. Melakukan konservasi mataair yang ada si dalam DAS,

2. Melakukan kegiatan pemanenan hujan baik dari rumah penduduk langsung atau dapat dilakukan dengan membuat waduk-waduk kecil. Hal ini karena kemampuan DAS juwet dalam menyimpan air di dalam tanah sangat terbatas. Hal tersebut disebabkan karena lapisan tanah yang tipis dan keberadaan batuan gunungapi yang kedap pada beberapa formasi misalnya batuan breksi vulkanik yang merupakan bagian dari Formasi Nglanggran.

\section{E. Penyelesaian Masalah Tekanan Penduduk}

Penyelesaian masalah tekanan penduduk dapat diselesaikan dengan:

1. Membuka lapangan kerja baru di luar sektor pertanian.

2. Meningkatkan hasil pertanian dengan menggunakan intensifikasi pertanian.

3. Melakukan pelatihan-pelatihan untuk dapat mendorong timbulnya ide krestif untuk membuka lapangan kerja baru.

4. Pemberian modal usaha dengan bunga rendah atau tidak berbunga kepada masyarakat.

5. Melakukan pembangunan infrastruktur untuk mendukung perkembangan perekonomian di DAS Juwet khususnya di Kecamatan Gedangsari.

\section{DAFTAR PUSTAKA}

Asdak, Chay. 2007. Hidrologi dan Pengelolaan Daerah Aliran Sungai Edisi IV. Yogyakarta: Gadjah Mada University Press.

Ashari, Arif. 2010. Kehilangan Karbon Organik Dalam Tanah Oleh Aliran Permukaan di Daerah Aliran Sungai Opak Propinsi Daerah Istimewa Yogyakarta. Tesis S2, Program Studi Geografi Sekolah Pascasarjana Universitas Gadjah Mada Yogyakarta (tidak dipublikasikan).

Azis, Sulthani. 2008. Evaluasi Kemampuan Lahan dan Pendugaan Erosi untuk Arahan Pemanfaatan Lahan Wilayah Sub DAS Juwet dan Dondong, Gunungkidul, Yogyakarta. Tesis S2. Program Studi Geografi Magister Perencanaan Pengelolaan Pesisir dan Daerah Aliran Sungai, Sekolah Pasca Sarjana Universitas Gadjah Mada.

Balai Penelitian Tanah, Balai Besar Litbang Sumber Daya Lahan Pertanian, Badan Penelitian dan Pengembangan Pertanian, Departemen Pertanian Republik Indonesia. 2009. Petunjuk Teknis Analisis Kimia Tanah, Tanaman, Air dan Pupuk. Bogor: Agro Inovasi.

Bengen, D.G. 2004. Menuju Pengelolaan Daerah Pesisir Terpadu Berbasis Daerah Aliran Sungai (DAS). Dalam: W. B. Setyawan, P. Purwati, S. Sunanisari, D. Widarto, R. nasution, dan O. 
Atijah (eds), Interaksi Daratan dan Lautan: Pengaruhnya terhadap Sumberdaya dan Lingkungan. Prosiding Simposium Interaksi Daratan dan Lautan, Kedeputian IImu Pengetahuan Kebumian, Lembaga Ilmu Pengetahuan Indonesia, Jakarta, Indonesia, 21-41.

Both ENDS dan Gomukh. 2005. Pengelolaan Daerah Aliran Sungai, Terjemahan Henny Soelistyowati dan Hardono Hadi. Yogyakarta: Insist Press.

Cahyadi, Ahmad; Nurjani, Emilya; Haryono, Eko; dan Nugraha, Henky. 2011. Estimation of Soil Organic Carbon Loss by Runoff and It's Role on Management of Ungauge Watershed. Makalah dalam $3^{\text {rd }}$ International Seminar on Applied Technology, Science and Art 2011. Institut Teknologi Sepuluh November, 6-7 Desember 2011.

Murdiyarso, Daniel. 2003. Sepuluh Tahun Perjalanan Negosiasi Konvensi Perubahan Iklim. Jakarta: Kompas.

Puspasari, Sofi. 2010. Studi Hubungan Nilai Koefisien Limpasan Permukaan dengan Indikator Intensitas Kehilangan Tanah Berdasarkan Kenampakkan Mikrotopografi Erosi di Sub DAS Juwet. Skripsi S1. Fakultas Geografi Universitas Gadjah Mada Yogyakarta. (tidak dipublikasikan).

Rahim, Supli Effendi. 1996. Pengendalian Erosi Tanah: Dalam Rangka Pelestarian Lingkungan Hidup, Cetakan Ketiga. Jakarta: Bumi Aksara.

Seyhan, Ersin. 1990. Dasar-Dasar Hidrologi (terjemahan Sentot Subagyo). Yogyakarta: Gadjah Mada University Press.

Triatmodjo, Bambang. 2009. Hidrologi Terapan. Yogyakarta: Beta Offset.

Utomo, Wani Hadi. 1994. Erosi dan Konservasi Tanah. Malang: Penerbit IKIP Malang.

Worosuprojo, S; Nurjani, Emilya dan Ashari, Arief (2010). Redistribusi Karbon oleh Erosi dan Banjir di DAS Oyo. Laporan Penelitian. Fakultas Geografi Universitas Gadjah Mada Yogyakarta. 